\section{Mixed Periapical Lesion: An Atypical Radicular Cyst with Extensive Calcifications}

Flávia Maria de Moraes Ramos-Perez ${ }^{1}$, Andréa dos Anjos Pontual' ${ }^{1}$ Talita Ribeiro Tenório de França ${ }^{1}$, Maria Luiza dos Anjos Pontual ${ }^{1}$, Ricardo Villar Beltrão², Danyel Elias da Cruz Perez ${ }^{1}$

\author{
'Department of Clinical and \\ Preventive Dentistry, School of \\ Dentistry, UFPE - Federal University \\ of Pernambuco, Recife, PE, Brazil \\ ${ }^{2}$ Oral Radiology Section, UFPB \\ - Federal University of Paraiba, \\ João Pessoa, PB, Brazil
}

Correspondence: Prof. Dr. Danyel Elias da Cruz Perez, Avenida Prof. Moraes Rego, 1235, Cidade Universitária, 50670-901 Recife, PE, Brasil. Tel: +5581-2126-8817. Fax: +55-81-21268817. e-mail: danyel.perez@ufpe.br

The radicular cyst is an inflammatory odontogenic cyst of endodontic origin. Radiographically, the lesion appears as a periapical radiolucent image. This report describes a very rare case of a mixed periapical radiographic image diagnosed as a radicular cyst. A 37-year-old female patient presented a mixed, well-circumscribed image located in the periapical region of the left maxillary central incisor, which presented unsatisfactory endodontic treatment. Microscopic examination revealed a cavity lined by non-keratinized squamous epithelium and extensive calcifications in the cystic lumen and lining epithelium. Diagnosis of radicular cyst with extensive calcifications was established. Endodontic retreatment was performed and no radiographic signs of recurrence were observed 18 months after treatment. Although very rare, a radicular cyst should be considered in the differential diagnosis of a mixed periapical image associated to teeth with pulp necrosis.

Key Words: differential diagnosis, mixed radiographic image, periapical cyst, radicular cyst.

\section{Introduction}

The radicular cyst $(\mathrm{RC})$ represents the most common odontogenic cyst (1). The lesion arises from the proliferation of epithelial rests of Malassez induced by inflammatory cytokines and growth factors released by inflammatory cells found in chronic apical periodontitis following root canal infection and pulp necrosis $(2,3)$.

Radiographically, RC appears usually as a wellcircumscribed periapical radiolucent image in a tooth with pulp necrosis (3). Presence of calcifications is commonly observed in RC, but it is usually discrete and observed only in histopathological analysis (4). RC appearing as a mixed radiographic image is very rare. A review of the literature revealed one well-documented case of mixed radiographic image diagnosed as residual $\mathrm{RC}$ (5). The aim of this report is to describe an unusual case of a periapical mixed radiographic image diagnosed as $\mathrm{RC}$.

\section{Case Report}

A 37-year-old female patient was attended in a private dental clinic for a swelling in the anterior region of the maxilla. The medical history was non-contributory. In intraoral examination, an expansion of buccal cortical bone in the region of the maxillary left central incisor was observed. The swelling presented firm consistency, the superficial mucosa was intact and showing normal color. Cone beam computed tomography revealed a mixed, wellcircumscribed image located in the periapical region of the maxillary left central incisor, which presented prosthetic crown and unsatisfactory endodontic treatment (Fig. 1). The lesion showed great amount of hyperdense foci that caused enlargement and disruption of the buccal cortical bone and measured $2.0 \mathrm{~cm}$ (Fig. 2). Calcifying cystic odontogenic tumor, ossifying fibroma and adenomatoid odontogenic tumor were the hypotheses of diagnosis. Thus, under local anesthesia, the lesion was excised and sent for histopathological analysis.

The macroscopic examination showed a round and brownish soft tissue with a smooth surface. The lesion was sectioned and several yellowish granules with hard consistency were observed (Fig. 3). Microscopically, a cavity lined by the non-keratinized, hyperplastic and squamous epithelium was observed. The fibrous capsule had a moderate chronic inflammatory reaction and extensive calcifications, which were also noted in the cystic lumen and epithelial lining. These calcifications
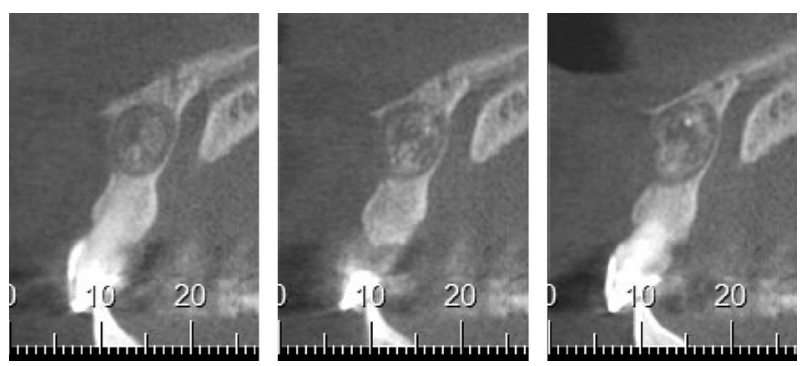

Figure 1. Parasagittal views show well-circumscribed mixed image in the periapical region. 
appeared as elongated or granular structures widely distributed throughout the lesion. Deposits of cholesterol crystals were commonly observed in the fibrous capsule. The epithelial basal cells were flattened (Fig. 4). These findings established the diagnosis of RC with extensive calcifications.

Nonsurgical endodontic retreatment was performed in the left maxillary central incisor and after 8 months of the surgery a full new bone formation was observed. There were no radiographic signs of recurrence 18 months after the treatment.

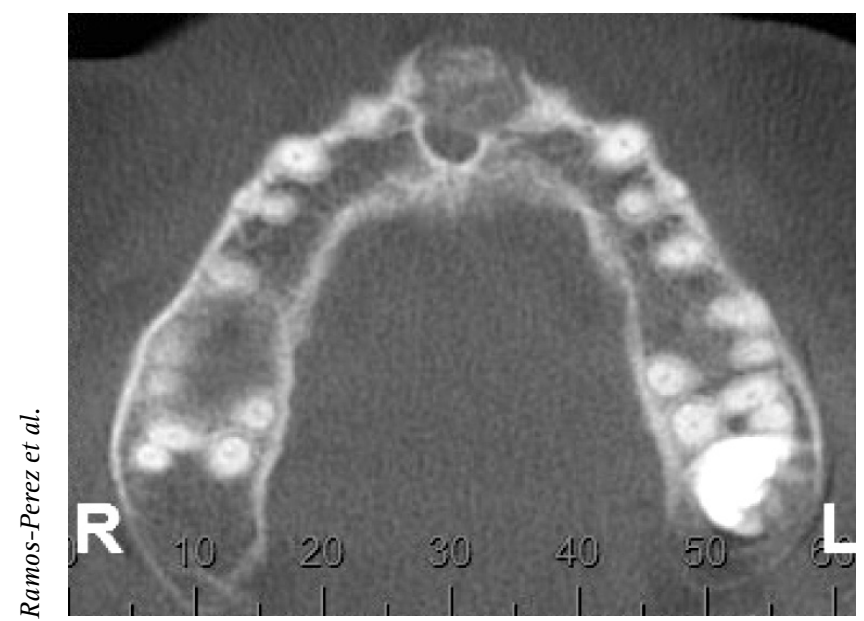

Figure 2. Axial view showing enlargement and disruption of the buccal cortical bone.

\section{Discussion}

$\mathrm{RC}$ is an inflammatory odontogenic cyst of endodontic origin. Radiographically it is indistinguishable from the periapical granuloma, except for large lesions. Both lesions appear as well-circumscribed, unilocular, round-to-oval radiolucent periapical images in teeth with pulp necrosis, and associated with disruption of the lamina dura of the affected teeth (2). The occurrence of RC as a mixed radiographic image is extremely rare (5).

Several diseases of the jaws may appear as a welldelimited mixed radiographic image. Ossifying fibroma,

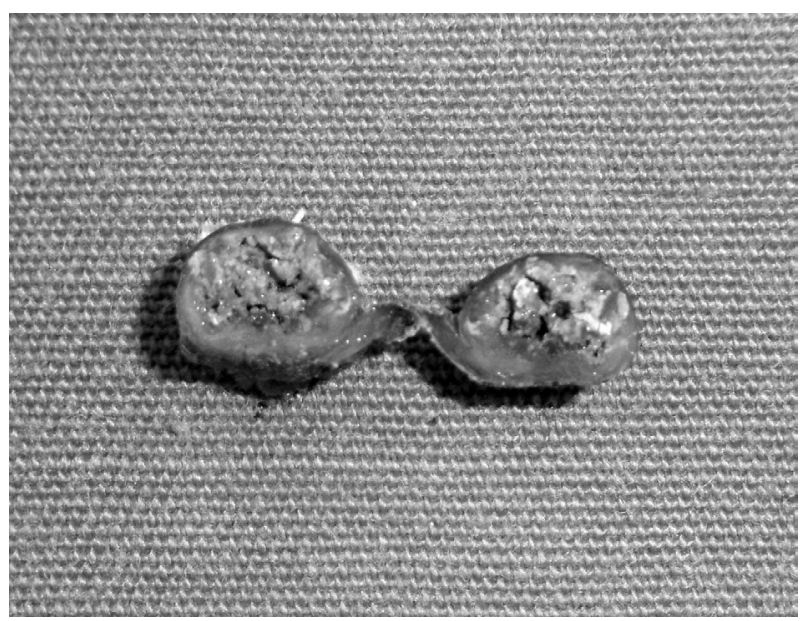

Figure 3. Macroscopic examination revealed several granules of hard consistency within the lesion.
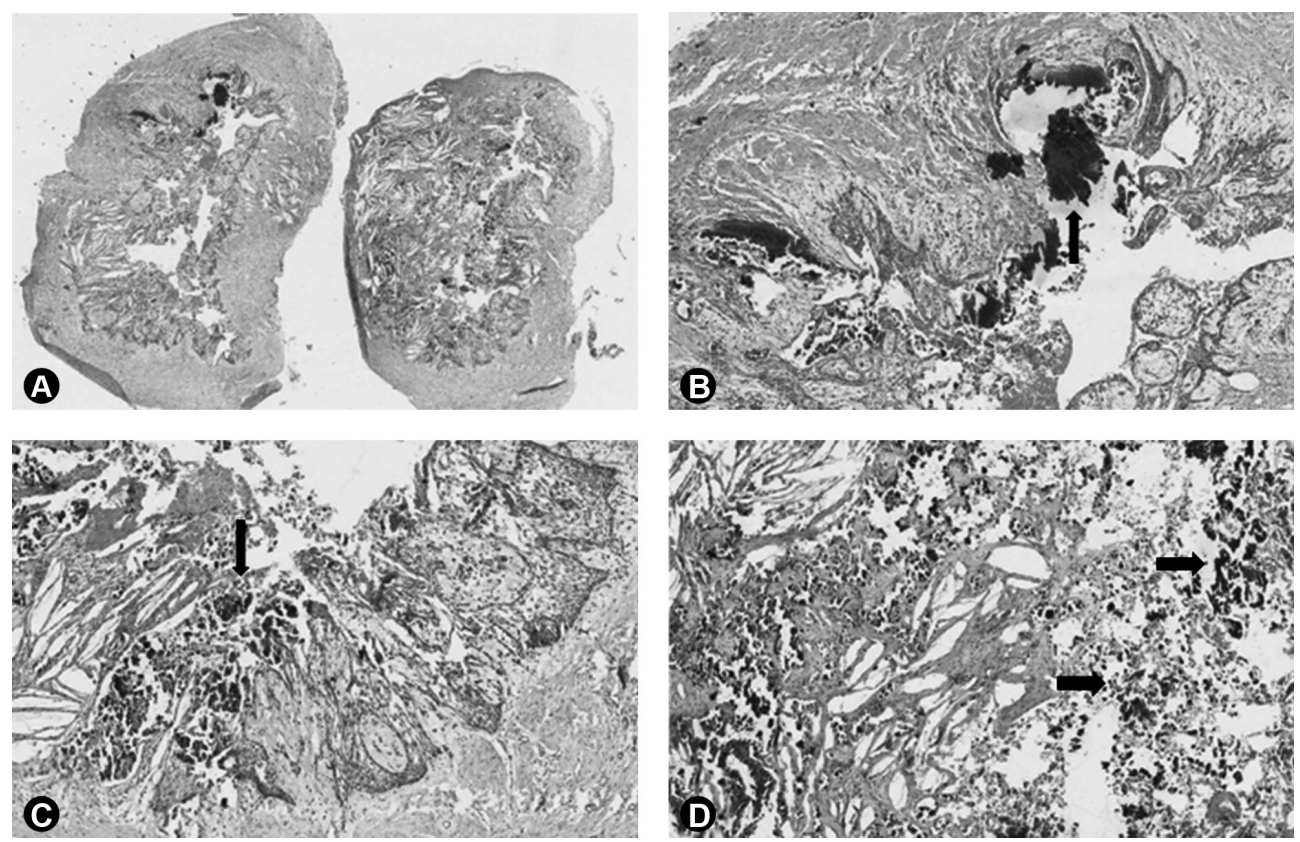

Figure 4. A. Panoramic histopathological exam revealing the cystic cavity (HE, 10x). B. Elongated and granular calcified structures located in the fibrous capsule and lining epithelium (arrow) (40x, HE). C. Cystic cavity lined by the non-keratinized, hyperplasic and squamous epithelium associated with granular calcifications (arrow). Epithelial basal cells appear flattened (50x, HE). D. Fibrous capsule presenting extensive calcifications (arrows) and deposits of cholesterol crystals (100x, HE). 
calcifying cystic odontogenic tumor, adenomatoid odontogenic tumor, calcifying epithelial odontogenic tumor and osseous dysplasia are among these lesions (6-12). Ossifying fibroma occurs more frequently in the posterior region of the mandible of patients between the second and fourth decades of life $(6,9)$. The anterior region of the maxilla is the most common site for an adenomatoid odontogenic tumor, which occurs predominantly in children and adolescents. Most cases are associated with an unerupted tooth (8). The calcifying cystic odontogenic tumor affects equally maxilla and mandible, and one-third of the cases are associated with an unerupted tooth. Root resorption and displacement of the involved teeth are common findings (11). Although the present case does not show the usual features, ossifying fibroma, adenomatoid odontogenic tumor and calcifying cystic odontogenic tumor were considered in the differential diagnosis because habitually they appear as mixed images. These lesions have also been reported in the periapical region $(7,13,14)$. Additionally, in approximately $70 \%$ of cases of non-endodontic periapical lesions, the affected teeth presented pulp necrosis or were endodontically treated (14). Different from the current case, the calcifying epithelial odontogenic tumor affects primarily the posterior region of the mandible and presents a unilocular or multilocular image with varying amounts of radiopaque foci (10).

Osseous dysplasias are benign fibro-osseous lesions typically located in periapical regions of usually vital teeth. The radiodensity varies according to the amount of mineralized tissue within the lesion, ranging from predominantly radiolucent to radiopaque, or mixed (12). Depending on the clinico-radiographic presentation, different terms are used. Unlike this case, periapical osseous dysplasias are lesions located in the anterior region of the mandible and affect few adjacent teeth, whereas the condition occurring in the posterior region of the jaws is called focal osseous dysplasia (15). In addition, osseous dysplasias rarely cause enlargement of the cortical bone. Some authors postulate that focal osseous dysplasia and periapical osseous dysplasia represent the same disease at different locations (12).

Microscopically, the RC presents a cystic cavity usually lined by non-keratinized stratified squamous epithelium. The epithelial thickness varies depending on the stage of the lesion and the inflammatory reaction level in the fibrous capsule (3). Dystrophic calcifications may be observed in approximately $15 \%$ of RC (4). A study evaluated a series of residual $\mathrm{RC}$ and revealed that mineralization increases with time. However, the amount of calcifications usually does not reflect in mixed radiographic images $(3,4)$. Particularly in this case, overfilling probably occurred during endodontic treatment, and the root canal sealer caused degeneration or tissue necrosis and consequent formation of extensive dystrophic calcifications. In addition, several root canal sealers have calcium in their composition, alkaline $\mathrm{pH}$ (16), enhancing the dystrophic calcification formation (5). Another hypothesis is that part of the granulated material observed in the cystic lumen and capsule is root canal sealer that extraverted during the endodontic treatment performed in the affected tooth. Thus, overfilling should be avoided to prevent injuries in the periapical tissues. Moreover, the biocompatibility and cytotoxicity tests are essential for selecting the most adequate root canal sealer (17-19) and to prevent such consequences. In the current case, the root canal sealer used prior to the patient's referral for diagnosis was unknown.

The treatment for chronic periapical lesions, including $\mathrm{RC}$, is nonsurgical endodontic treatment and follow-up of the patient until complete bone repair $(2,14)$. However, periapical lesions that do not heal after adequate endodontic treatment or have an unusual radiographic image should be submitted to surgical excision (14) and the surgical specimen should be sent for histopathological analysis, as was done in the present case.

In summary, although a unilocular periapical radiolucent image is the typical radiographic presentation of $\mathrm{RC}$, this lesion should also be considered in the differential diagnosis of mixed radiographic images located in the periapical region of teeth with pulp necrosis. Patients with periapical radiolucent lesions submitted to endodontic treatment should be followed-up until the lesions healed completely.

\section{Resumo}

0 cisto radicular é um cisto odontogênico inflamatório de origem endodôntica. Radiograficamente, a lesão se apresenta como uma imagem radiolúcida periapical. Este relato descreve um caso muito raro de uma imagem radiográfica periapical mista diagnosticada como cisto radicular. Uma paciente de 37 anos de idade, do gênero feminino, apresentava uma imagem mista, bem circunscrita, localizada na região periapical do incisivo central superior esquerdo, que apresentava tratamento endodôntico insatisfatório. Avaliação microscópica revelou uma cavidade revestida por epitélio escamoso não-queratinizado e calcificações extensas na cavidade cistica e revestimento epitelial. 0 diagnóstico de cisto radicular com extensas calcificações foi estabelecido. Retratamento endodôntico foi realizado e não foram observados sinais radiográficos de recorrência da lesão após 18 meses de tratamento. Embora muito raro, um cisto radicular deve ser considerado no diagnóstico diferencial de uma imagem periapical mista associada a dentes com necrose pulpar.

\section{References}

1. Tekkesin MS, Olgac V, Aksakalli N, Alatli C. Odontogenic and nonodontogenic cysts in Istanbul: analysis of 5088 cases. Head Neck 2012;34:852-855.

2. Lin LM, Ricucci D, Lin J, Rosenberg PA. Nonsurgical root canal therapy of large cyst-like inflammatory periapical lesions and inflammatory apical cysts. J Endod 2009;35:607-615.

3. Shear M, Speight PM. Cysts of the maxilofacial regions. 4th ed. Oxford: Blackwell Munksgaard; 2007.

4. Lin HP, Chen HM, Yu CH, Kuo RC, Kuo YS, Wang YP. Clinicopathological 
study of 252 jaw bone periapical lesions from a private pathology laboratory. J Formos Med Assoc 2010;109:810-818.

5. Krithika C, Kota S, Gopal KS, Koteeswaran D. Mixed periapical lesion: differential diagnosis of a case. Dentomaxillofac Radiol 2011;40:191194.

6. Andrade M, Silva-Sousa YT, Marques MF, Pontual ML, Ramos-Perez FM, Perez DE. Ossifying fibroma of the jaws: a clinicopathological case series study. Braz Dent J 2013;24:662-666.

7. Moraes Ramos-Perez FM, Soares UN, Silva-Sousa YT, Cruz Perez DE. Ossifying fibroma misdiagnosed as chronic apical periodontitis. J Endod 2010;36:546-548.

8. Matos FR, Nonaka CF, Pinto LP, Souza LB, Almeida Freitas R. Adenomatoid odontogenic tumor: retrospective study of 15 cases with emphasis on histopathologic features. Head Neck Pathol 2012;6:430437.

9. de Noronha Santos Netto J, Machado Cerri J, Miranda AM, Pires FR. Benign fibro-osseous lesions: clinicopathologic features from 143 cases diagnosed in an oral diagnosis setting. Oral Surg Oral Med Oral Pathol Oral Radiol 2013;115:e56-e65.

10. Philipsen HP, Reichart PA. Calcifying epithelial odontogenic tumour: biological profile based on 181 cases from the literature. Oral Oncol 2000;36:17-26.

11. Praetorius $F$, Ledesma-Montes $C$. Calcifying cystic odontogenic tumour. In: Pathology and genetics head and neck tumors. Barnes L, Eveson JW, Reichart P, Sidransky D (editors). 1st ed. Lyon: IARC Press; 2005. p. 313.

12. Su L, Weathers DR, Waldron CA. Distinguishing features of focal cemento-osseous dysplasia and cemento-ossifying fibromas. II. A clinical and radiologic spectrum of 316 cases. Oral Surg Oral Med Oral Pathol Oral Radiol Endod 1997;84:540-549.

13. Philipsen HP, Srisuwan T, Reichart PA. Adenomatoid odontogenic tumor mimicking a periapical (radicular) cyst: a case report. Oral Surg Oral Med Oral Pathol Oral Radiol Endod 2002;94:246-248.

14. Ortega A, Fariña V, Gallardo A, Espinoza I, Acosta S. Nonendodontic periapical lesions: a retrospective study in Chile. Int Endod J 2007;40:386-390.

15. Slootweg PJ. Lesions of the jaws. Histopathology 2009;54:401-418.

16. Parirokh $M$, Torabinejad $M$. Mineral trioxide aggregate: a comprehensive literature review-Part I: chemical, physical, and antibacterial properties. J Endod 2010;36:16-27.

17. Campos-Pinto MM, Oliveira DA, Versiani MA, Silva-Sousa YT, SousaNeto MD, Cruz Perez DE. Assessment of the biocompatibility of Epiphany root canal sealer in rat subcutaneous tissues. Oral Surg Oral Med Oral Pathol Oral Radiol Endod 2008;105:e77-e81.

18. Silva EJ, Rosa TP, Herrera DR, Jacinto RC, Gomes BP, Zaia AA. Evaluation of cytotoxicity and physicochemical properties of calcium silicatebased endodontic sealer MTA Fillapex. J Endod 2013;39:274-277.

19. Silva-Herzog D, Ramírez T, Mora J, Pozos AJ, Silva LA, Silva RA, et al.. Preliminary study of the inflammatory response to subcutaneous implantation of three root canal sealers. Int Endod J 2011;44:440-446.

Received July 19, 2014 Accepted September 30, 2014 